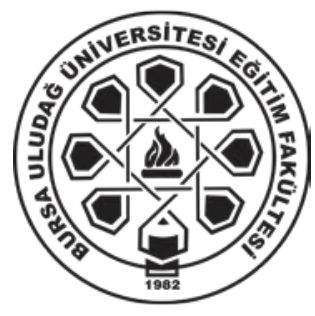

Bursa Uludağ Üniversitesi

Ĕ̆itim Fakültesi

Dergisi

Araştırma Makalesi

https://dx.doi.org/10.19171/uefad.533032

Başvuru/Received: 30.06.2018 Kabul/Accepted: 11.12.2018

\title{
Okul Öncesi Öğretmen Adaylarının Akademik İçsel Motivasyonları İle Özliderlik Düzeyleri Arasındaki İlişki
}

\author{
Ayşe ÇUBUKCU \\ Yüksek Lisans Öğrencisi, Uludă̆ Üniversitesi Ĕ̈itim Bilimleri Enstitüsü, \\ cubukcuayse@gmail.com,OrcID: 0000-0002-3704-8994 \\ Pınar BAĞÇELİ KAHRAMAN \\ Dr. Öğretim Üyesi, Uludă̆ Üniversitesi Eğitim Fakültesi, \\ pinarbag@uludag.edu.tr, OrcID: 0000-0002-0551-7741
}

\section{ÖZET}

$\mathrm{Bu}$ araştırma okul öncesi öğretmen adaylarının akademik içsel motivasyonları ile özliderlik düzeyleri arasındaki ilişkiyi belirlemek amacıyla yapılmıştır. Araştırma ilişkisel tarama modelinde gerçekleştirilmiştir. Araştırma grubunu 2017-2018 eğitim-öğretim yılında Uludağ Üniversitesi Eğitim Fakültesi Temel Eğitim Bölümü Okul Öncesi Eğitimi Anabilim Dalı'nda öğrenim gören toplam 226 öğretmen adayı oluşturmaktadır. Araştırma verileri, Özliderlik Ölçeği ve Akademik İçsel Motivasyon Ölçeği ile Kişisel Bilgi Formu aracılığıyla toplanmıştır. Okul öncesi öğretmen adaylarının akademik içsel motivasyonları ile özliderlik düzeyleri arasındaki ilişki "Pearson Çarpım Momentler Korelasyon Katsayısı" ile belirlenmiştir. Ayrıca sınıf düzeyine göre okul öncesi öğretmen adaylarının akademik içsel motivasyonları ve özliderlik düzeyleri arasında farklılık olup olmadığ 1 da "Kruskal Wallis Testi" ile incelenmiştir. Araştırma neticesinde okul öncesi öğretmen adaylarının akademik içsel motivasyonları ile özliderlik düzeyleri arasında pozitif yönde anlamlı bir ilişki olduğu belirlenmiştir. Değişen dünyaya ayak 
uydurabilmek için öz liderlik düzeyi yüksek ve işini severek yapan bireylerin yetiştirilmesi gerekmektedir. Bu durum da öncelikle öğretmenlerin bu becerilerle donanmış olmasından geçmektedir.

Anahtar Kelimeler: Akademik içsel motivasyon, öz liderlik, okul öncesi, öğretmen adayı.

\title{
The Relation between Academic Internal Motivation and Self-Leadership Levels of Preschool Teacher Candidates
}

\begin{abstract}
This research was carried out in order to determine the relation between academic internal motivation and self-leadership levels of preschool teacher candidates. The research was carried out in the relational scanning model. The study group of the research consists of totally 226 teacher candidates who attend Uludag University Faculty of Education Preschool Education Department in 2017-2018 education year. Within the research Self-leadership Scale and also Academic Internal Motivation Scale and Personal Information From were used. The relation between academic internal motivation and self-leadership levels of preschool teacher candidates was determined with "Pearson Product Moment Correlation Coefficient". In addition whether there is a difference between academic interval motivation and the self-leadership of the preschool teacher candidates according to class grade was examined by "Kruskal Wallis Test". As a result of the research it was determined that there is relation between academic interval motivation and the self-leadership of the preschool teacher candidates positively. In order to keep up with the changing world it is necessary to rear teachers who have high level of self-leadership and like doing their job.
\end{abstract}

Key Words: Academic internal motivation, self-leadership, preschool, teacher candidates.

\section{GIRIŞ}

Günümüzde yaşanan teknolojik ve bilimsel değişimlerin bir sonucu olarak, öğrenciyi etkin kılan, onları güdüleyen ve diğer öğrenci, öğretmen ve yöneticilerle işbirliği yapan öğretmenlere ihtiyaç duyulmaktadır. Bu bağlamda olumlu bir okul iklimi yaratmak oldukça önemlidir. Yöneticileri, velileri ve öğrencileri tarafından değer gören bir öğretmen mesleğine karş1 daha olumlu duygular geliştirecektir. Kocabaş ve Karaköse (2005) yöneticilerin tutum ve davranışlarının öğretmenlerin motivasyonuna olan etkisini incelemek amacıyla yaptıkları araştırmada, yönetim ve iletişim 
becerileri ile takdir etme ve fark etme tutumlarına sahip yöneticilerin ögretmen motivasyonu üzerinde olumlu bir etkiye sahip olduğunu ortaya koymuşlardır. Ayrıca eğitim-öğretim süreci içerisinde öğretmenlerin motivasyonunu yükseltmek amacıyla çeşitli toplantılar, faaliyetler düzenlenmeli ve eğitim-öğretim sırasında öğretmenin sürecin içinde daha etkin ve verimli olabileceği yeni öğretim programları tasarlanmalıdır (Koyuncu, 2016). Böylelikle öğretmenlerin içsel motivasyonları artacak ve verimli bir eğitim-öğretim sürecinin oluşmasına da zemin hazırlanacaktır. Dolayısıyla öğrenme ortamlarının değişmesi, öğrencilerin değişen bu ihtiyaçlarının karşılanabilmesi ancak içsel motivasyonu yüksek, kendi gücünü bilen ve doğru kullanabilen öğretmenlerle mümkün olacaktır. Çünkü öğretmenlerin öğrencileri motive edebilmesi öncelikle onların kendi motivasyonlarını yönetebilmelerine yani içsel motivasyonlarının yüksek olmasına bağlıdır. Ayrıca öğretmenlerin; kendilerine doğru bir gelecek belirleyen, yeteneklerini tanıyan ve en üst düzeyde geliştiren bireyler olmaları yani öz liderlik alg1 düzeyleri yüksek bireyler olmaları, öğrencilerine doğru yön verebilmelerinde etkili olmakta ve bu nedenle öğretmenlerin liderlik davranışlarının desteklenmesi önem kazanmaktadır (Beycioğlu ve Aslan, 2010).

Elloy (2008) öz liderliğin ortak çalışmalarda aranan özelliklerden biri olduğunu ifade etmektedir. Manz (1986) da öz liderliği, bireylerin belirli davranışsal ve bilişsel yöntemler aracılığıyla başarılı olma yolunda kendilerini ve davranışlarını düzenledikleri bir süreç olarak açıklamaktadır. Dolayısıyla, öz liderlik, bireyin kendini motive etmesini gerektiren bir kavram olarak karşımıza çıkmaktadır. Manz (Manz, 1992: Akt. Prussia, Anderson ve Manz, 1998) öz liderliğin, yapıcı düşünce model stratejileri (constructive thought pattern strategies), davranış odaklı strateji (behaviorfocused strategies) ve doğal ödül stratejileri (natural reward strategies) olmak üzere üç birbirini tamamlayıcı stratejiden oluştuğunu öne sürmektedir. Davranış odaklı stratejiler kendine hatırlatıcılar belirleme, hedef belirleme, kendini cezalandırma, kendini gözlemleme, kendini ödüllendirme gibi boyutlardan oluşmaktadır. Yapıcı düşünce model stratejileri ise; kendi kendine konuşma, başarılı performans hayal etme, düşünce ve fikirlerini değerlendirme kısımlarından oluşmakta olup; doğal ödül stratejileri de bireyin hoşuna gitmeyen davranışları yapmaktan kaçınmasını ve hoşuna giden davranışları sıklıkla sergilemesini kapsamaktadır. (Manz, 1992: Akt. Prussia, Anderson ve Manz, 1998). Kısaca öz liderliğin yüksek olması, bireylerin performanslarını olumlu yönde etkileyen sorumluluk ve kontrol becerisinin de yüksek olduğunu göstermektedir. Bu nedenle öz liderliğin bireylerin davranışlarını etkileyen önemli bir etmen olduğu için incelenmesi 
gerektiği ifade edilmektedir (Prussia, Anderson ve Manz, 1998; Stewart, Courtright ve Manz, 2011). Zapalska, Kelley ve Zieser (2015) de eğitimin bütün kademelerinde öz liderliğin geliştirilmesine yönelik etkinliklerin yapılmas1 gerektiğini belirtmektedirler.

Motive olma eylemi olarak açılanan motivasyon, tüm eğitim kademelerinde öğrencilerin tutumlarını ve davranışlarını etkilemektedir. Motivasyon içsel ve dişsal motivasyon ve motivasyonsuzluk olmak üzere üç çeşidi vardır. Eğitimciler için önemli olan içsel motivasyon, bir işi zevk alındığı için yapmayı; dışsal motivasyon ise sonucunda elde edilecek olanlar için işi yapmayı kapsamaktadır. Öğretmenlik mesleğinde oldukça önemli bir yeri olan motivasyon sürecinde; dişsal faktörler oldukça etkili olsa da ögretmenin içsel motivasyonunun yüksek olması çok daha önemlidir. Dışsal faktörler her ne kadar iyi olsa da içsel olarak güdülenmeyen ve motive olmayan bir öğretmen mesleğinde mutlu ve verimli olamamaktadır. İçsel motivasyon öğrenmeye ve öğretmeye üst düzeyde katkı sağlamaktadır (Ryan ve Deci, 2000). Motivasyonun etkisi bireyin kişisel gelişimine göre değişse de öğretmenlerden beklenen içsel motivasyonu yüksek bireyler olmalarıdır (Yazıc1, 2009). Akademik motivasyon ise, akademik olarak öğrenmeye hazır olmak olarak açıklanabilmektedir (Wilkesmann, Fischer ve Virgilito, 2012). Motivasyon; bir işi mükemmeli hedefleyerek yapmaya çalışmayı ifade eden başarı gereksinimi, başarılı olamayacağı korkusunu içeren başarısızlık korkusu, davranışların diğer insanlar tarafından beğenilmesi gereksinimini oluşturan sosyal kabul gereksinimi ve kendi gücü ve yetenekleri ile başkalarına ihtiyaç duymadan bir işi yapabilmeyi içeren uzmanlık alt boyutlarından oluşmaktadır (Jacobsen, Eggen ve Kauchak, 2002; Öztürk, 2006). Öğretmenlerin ruh sağlıklarını, düşünce yapılarını ve iletişim becerilerini pozitif olarak etkileyip motive olmalarını sağlayan birtakım temel tutumlar vardır: Bir öğretmenin kendi ihtiyaçları ve duygularını benimsemesini ifade eden öz-farkındalık, öğretmenin söyledikleriyle uyguladıkları arasındaki oranı ifade eden tutarlılık, öğrencileri ne yaparsa yapsın onlara değer vermesi gerektiğini belirten koşulsuz olumlu kabul, açık ve gerçeğe uygun davranışı ifade eden doğallık-içtenlik, empati ve iletişim becerileri (Yazıcı, 2009). Bu tutumlara sahip bir öğretmen daha üst düzeyde içsel motivasyona sahip olacaktır. İçsel motivasyonu yüksek bir öğretmen de mesleğini daha başarılı bir biçimde yapmak için çaba gösterecektir. Çünkü içten güdülenen birey hedefine ulaşmak için gereken çabayı kendi isteği ile gösterirken, diştan güdülenen birey bu çabayı bir ödüle ulaşmak ya da bir cezadan kaçmak için gösterebilmektedir (Ryan ve Deci, 2000). Bu durumda öğretmenin davranışları öğrencilerin okul memnuniyeti, okula devam 
durumları, derse katılım, ödev başarıları gibi eğitsel faktörler üzerinde de etkili olmaktadır (Uyulgan ve Akuzu, 2014).

Okul öncesi dönemden başlayarak içsel motivasyonu yüksek ve öz liderlik algıları yüksek bireylerin yetiştirilmesi, ancak kendisi bu özelliklere sahip öğretmenlerle olacaktır. Öğretmen adaylarının bu özelliklerinin belirlenmesi ise, öğretmenliğe başlamadan önce bu özelliklerin geliştirilebilmesi açısından önem taşımaktadır. Bu araştırmanın amacı okul öncesi öğretmen adaylarının içsel motivasyonları ile öz liderlik alg1 düzeyleri arasındaki ilişkinin çeşitli değişkenler açısından incelenmesidir.

\section{YÖNTEM}

\section{Araştırma Modeli}

Okul öncesi öğretmenliği öğretmen adaylarının akademik içsel motivasyonları ile özliderlik düzeylerini saptamaya yönelik olarak yapılan bu araştırmada değişkenler arasındaki ilişkiyi belirlemek amacıyla kullanılan ilişkisel tarama modeli kullanılmıştır (Karasar, 2009; Büyüköztürk ve diğ, 2011).

\section{Çalışma Grubu}

Tablo 1. Çalışma grubunun dağılım tablosu

\begin{tabular}{llcc}
\hline & & f & \% \\
\hline \multirow{3}{*}{ Sinıf Düzeyi } & 1.sınıf & 51 & 22,6 \\
& 2. sınıf & 64 & 28,3 \\
& 3. sınıf & 54 & 23,9 \\
Yaş & 4. sınıf & 57 & 25,2 \\
& 20 yaş ve altı & 84 & 37,2 \\
Cinsiyet & 21 yaş ve üstü & 142 & 62,8 \\
& Kiz & 205 & 90,7 \\
Tercih Sebebi & Erkek & 21 & 9,3 \\
\multirow{2}{*}{ Mesleği Yapma } & İsteyerek & 199 & 88,1 \\
İsteği & İstemeyerek & 27 & 11,9 \\
\hline
\end{tabular}

Araştırmanın çalışma grubunu Uludağ Üniversitesi Temel Eğitim Bölümü Okul Öncesi Eğitimi Anabilim Dalı'nda öğrenim görmekte olan 51 $(\% 22,6)$ birinci sınıf, $64(\% 28,3)$ ikinci sınıf, $54(\% 23,9)$ üçüncü sınıf ve 57 
$(\% 25,2)$ dördüncü sınıf olmak üzere toplam 226 öğretmen aday1 oluşturmaktadır. Öğretmen adaylarının \%90,7'si (f=205) kadın, \%9,3'ü (f=21) erkek; 84'ü (\%37,2) 20 yaş ve altı, 142'si $(\% 62,8) 21$ yaş ve üstündedir. Öğretmen adaylarının \%88,1'i (f=199) öğretmenliği kendi isteği ile tercih etmiştir ve \%92'si (f=208) öğretmen olmak istemektedir.

\section{Veri Toplama Aracı}

Araştırmada Shia (1998) tarafından geliştirilen ve Uyulgan ve Akkuzu (2014) tarafından Türkçeye uyarlanmış olan 'Akademik İçsel Motivasyon Ölçeği' ve Anderson ve Prussia (1997) tarafından geliştirilen ve Tabak, Sığrı ve Türköz (2013) tarafından Türkçeye uyarlanan 'Öz Liderlik Ölçeği' kullanılmıştır.

\section{Akademik İçsel Motivasyon Ölçeği}

Uyulgan ve Akkuzu (2014) tarafindan Türkçeye uyarlanan 'Akademik İçsel Motivasyon Ölçeği' içsel ve dışsal birtakım faktörlerin akademik içsel motivasyonla ilişkisini belirlemek amacıyla geliştirilmiştir. Sosyal kabul, başarı gereksinimi, uzmanlık ve başarısızlık korkusu olmak üzere toplam 4 alt boyutu içeren Akademik İçsel Motivasyon Ölçeği'nden alınan toplam puan ne kadar yüksekse akademik içsel motivasyonun da yüksek olduğu anlamına gelmektedir. 23 maddeden ve 7'li likert tipten oluşan akademik içsel motivasyon ölçeği "7= beni yüksek derecede ifade ediyor" ve “ $1=$ beni yüksek derecede ifade etmiyor” şeklinde sıralanmaktadır. Ölçeğin cronbach alpha güvenirlik katsayısı .77 olarak belirlenmiştir. Bu araştırma kapsamında ölçeğin cronbach alpha güvenirlik katsayısı hesaplanmış ve .77 olarak belirlenmiştir. Alt ölçeklerin güvenirlik katsayıları ise Başarı Gereksinimi $\alpha=.88$, Sosyal Kabul .74, Başarısızlık korkusu .73 ve Uzmanlık .53 olarak belirlenmiştir. Ölçeğin güvenilir olduğu söylenebilir.

\section{Öz Liderlik Ölçeği}

Öz liderlik becerilerinin geliştirilebilmesi amaciyla Anderson ve Prussia (1997) tarafindan geliştirilen ve Tabak, Sığrı ve Türköz (2013) tarafindan Türkçeye uyarlanan Özliderlik Ölçeği, 29 maddeden oluşmakta olup 5'li likert tipinde (1=Hiçbir zaman, 2=Nadiren, 3=Ara sira, 4=Genellikle, 5=Her zaman) hazırlanmıştır. Ölçek Davranış Odaklı Stratejiler, Doğal Ödül Stratejileri ve Yapıcı Düşünce Model Stratejileri olmak üzere üç boyutlu ve 3 boyutlu ve 8 alt ölçek olarak hazırlanmıştır. Alt ölçekler kendini ödüllendirme $\alpha=.90$, kendi kendine konuşma $\alpha=.89$, kendine hedef belirleyerek başarılı performans hayal etme $\alpha=.88$, kendine hatırlatıcılar belirleme $\alpha=80$, kendini cezalandırma $\alpha=.76$, kendini 
gözlemleme $\alpha=.74$, düşünce/fikirleri değerlendirme $\alpha=.67$ ve doğal ödüller üzerinde düşünceyi odaklama $\alpha=.51$ olarak belirlenmiştir. Yapılan bu araştırmada da ölçeğin cronbach alpha güvenirlik katsayısı .89; alt ölçekler ise kendini ödüllendirme $\alpha=.85$, kendi kendine konuşma $\alpha=.91$, kendine hedef belirleyerek başarılı performans hayal etme $\alpha=.82$, kendine hatırlatıc1lar belirleme $\alpha=83$, kendini cezalandırma $\alpha=.77$, kendini gözlemleme $\alpha=.74$, düşünce/fikirleri değerlendirme $\alpha=.70$ ve doğal ödüller üzerinde düşünceyi odaklama $\alpha=.54$ olarak belirlenmiştir. Ölçeğin güvenilir olduğu söylenebilir.

\section{Verilerin Analizi}

Araştırma sonucunda elde edilen veriler SPSS (Statistical Package for Social Sciences) paket programı yardımıyla analiz edilmiştir. Verilerin çözümlenmesine başlamadan önce dağılımın normalliğine bakılmış; Kolmogorov-Smirnov testi sonucunda dağılımın normallik göstermediği görülmüştür. Bu nedenle okul öncesi eğitimi öğretmen adaylarının özliderlik ve akademik içsel motivasyonlarının sınıf düzeyine göre farklılık gösterip göstermediğine Kruskall Wallis-H (KWH) ile bakılmıştır. Anlamlı farklılık bulunan gruplar arasında da Mann Whitney U testinden yararlanılarak farklılığın kaynağı saptanmıştır. Ayrıca öğretmen adaylarının akademik içsel motivasyonları ile öz liderlik düzeyleri arasındaki ilişki Pearson Korelasyon Katsayısı tekniği yardımıyla çözümlenmiştir.

\section{BULGULAR VE YORUM}

Tablo 2. Okul öncesi eğitimi öğretmen adaylarının akademik içsel motivasyon ölçeğinden aldıkları puanlara ait betimsel istatistik sonuçları

\begin{tabular}{lccc}
\hline & $\mathrm{N}$ & $\bar{X}$ & Ss \\
\hline Başarı Gereksinimi & 226 & 36,21 & 6,99 \\
Sosyal kabul & 226 & 29 & 10,55 \\
Başarısızlık Korkusu & 226 & 16.54 & 6,24 \\
Uzmanlık & 226 & 20,48 & 4,80 \\
Toplam & 226 & 102,23 & 17,60 \\
\hline
\end{tabular}

Tablo 2 incelendiğinde; okul öncesi öğretmenliği öğretmen adaylarının Akademik İçsel Motivasyon Ölçeği'nden aldıkları ortalama puanın 102,23 olduğu görülmektedir. Ölçekten alınabilecek en yüksek 
puanın 161 olduğu düşünüldüğünde; öğretmen adaylarının akademik içsel motivasyonlarının ortalamanın üzerinde olduğu söylenebilir.

Tablo 3. Okul öncesi eğitimi öğretmen adaylarının öz liderlik ölçeğinden aldıkları puanlara ait betimsel istatistik sonuçları

\begin{tabular}{lccc}
\hline & $\mathrm{n}$ & $\bar{X}$ & ss \\
\hline Başarılı Performans hayal etme & 226 & 28,84 & 4,80 \\
Kendini Ödüllendirme & 226 & 11,55 & 2,96 \\
Kendi Kendine Konuşma & 226 & 11,58 & 2,81 \\
Düşünceleri Değerlendirme & 226 & 16,85 & 3,40 \\
Kendini gözlemleme & 226 & 7,65 & 1,46 \\
Kendini cezalandırma & 226 & 18,94 & 3,40 \\
Hatırlatıcılar belirleme & 226 & 7,29 & 2,21 \\
Düşünceye odaklanma & 226 & 8,35 & 1,43 \\
Toplam & 226 & 111,05 & 12,96 \\
\hline
\end{tabular}

Tablo 3 incelendiğinde; okul öncesi öğretmenliği öğretmen adaylarının Öz liderlik Ölçeğinden aldıkları ortalama puanın 111,05 olduğu görülmektedir. Ölçekten alınabilecek en yüksek puanın 145 olduğu düşünüldüğünde; öğretmen adaylarının öz liderlik düzeylerinin ortalamanın üzerinde olduğu söylenebilir. 
Tablo 4. Sınıf düzeylerine göre öğrencilerin akademik içsel motivasyon puanlarına ilişkin $\chi^{2}$ sonuçları

\begin{tabular}{|c|c|c|c|c|c|c|c|}
\hline & Sınıf Düzeyi & $\mathrm{N}$ & $\begin{array}{c}\text { Sira } \\
\text { Ortalamas1 }\end{array}$ & sd & $\chi^{2}$ & $\mathrm{p}$ & $\begin{array}{c}\text { Anlamlı } \\
\text { Fark }\end{array}$ \\
\hline \multirow{5}{*}{$\begin{array}{l}\text { Başarı } \\
\text { Gereksinimi }\end{array}$} & 1.sinif & 51 & 105,68 & \multirow{5}{*}{3} & \multirow{5}{*}{1.719} & \multirow{5}{*}{.633} & \\
\hline & 2.sinif & 64 & 118,27 & & & & \\
\hline & 3.sinif & 54 & 119,34 & & & & \\
\hline & 4.sinif & 57 & 109,61 & & & & \\
\hline & Toplam & 226 & & & & & \\
\hline \multirow{5}{*}{ Sosyal Kabul } & 1.sinıf & 51 & 134,85 & \multirow{5}{*}{3} & \multirow{5}{*}{7,918} & \multirow{5}{*}{$\begin{array}{c}.048 \\
*\end{array}$} & \\
\hline & 2.sinif & 64 & 101,90 & & & & 1.-2. Sinif \\
\hline & 3.sinif & 54 & 107,52 & & & & 1.-3. sinif \\
\hline & 4.sinif & 57 & 113,09 & & & & \\
\hline & Toplam & 226 & & & & & \\
\hline \multirow{5}{*}{$\begin{array}{l}\text { Başarısızlık } \\
\text { Korkusu }\end{array}$} & 1.sinıf & 51 & 116,12 & \multirow{5}{*}{3} & \multirow{5}{*}{.258} & \multirow{5}{*}{.968} & \\
\hline & 2.sinif & 64 & 110,77 & & & & \\
\hline & 3.sinif & 54 & 115,44 & & & & \\
\hline & 4.sinıf & 57 & 112,39 & & & & \\
\hline & Toplam & 226 & & & & & \\
\hline \multirow{5}{*}{ Uzmanlık } & 1.sinıf & 51 & 118,36 & \multirow{5}{*}{3} & \multirow{5}{*}{.613} & \multirow{5}{*}{.893} & \\
\hline & 2.sinıf & 64 & 110,05 & & & & \\
\hline & 3.sinif & 54 & 115,71 & & & & \\
\hline & 4.sinıf & 57 & 110,92 & & & & \\
\hline & Toplam & 226 & & & & & \\
\hline \multirow{5}{*}{ Toplam } & 1.sinıf & 51 & 120,52 & \multirow{5}{*}{3} & \multirow{5}{*}{1.047} & \multirow{5}{*}{.790} & \\
\hline & 2.sinif & 64 & 109,08 & & & & \\
\hline & 3.sinif & 54 & 115,32 & & & & \\
\hline & 4.sinif & 57 & 110,46 & & & & \\
\hline & Toplam & 226 & & & & & \\
\hline
\end{tabular}

Tablo 4 incelendiğinde; okul öncesi eğitimi öğretmen adaylarının akademik içsel motivasyonlarının sınıf düzeyine göre değişmediği görülmektedir ( $\chi_{(3)}^{2}=1.047 ; \mathrm{p}>.05$ ). Ancak sosyal kabul düzeylerinin sınıf düzeyine göre farklılaştığ düzeyindeki farklılaşmanın kaynağını bulmak amacıyla yapılan MannWhitney U Testi yapılmıştır. Buna göre birinci sınıf öğretmen adayları ile ikinci ve üçüncü sınıf öğretmen adayları arasında birinci sınıf öğretmen adayları lehine anlamlı farklılık tespit edilmiştir. Elde edilen bu sonuca göre; sınıf düzeyi değişse de öğretmen adaylarının akademik içsel motivasyonları değişmemektedir. 
A. Çubukcu ve P.B. Kahraman / Eğitim Fakültesi Dergisi 32 (1), 2019, 25-41

Tablo 5. Sınıf düzeylerine göre öğrencilerin öz liderlik puanlarına ilişkin $\chi^{2}$ sonuçları

\begin{tabular}{|c|c|c|c|c|c|c|}
\hline & Fakülte & $\mathrm{N}$ & $\begin{array}{c}\text { Sira } \\
\text { Ortalamas1 }\end{array}$ & sd & $\chi^{2}$ & $\mathrm{P}$ \\
\hline \multirow{5}{*}{$\begin{array}{l}\text { Başarılı } \\
\text { performans hayal } \\
\text { etme }\end{array}$} & 1.sinif & 51 & 108,53 & \multirow{5}{*}{3} & \multirow{5}{*}{3,060} & \multirow{5}{*}{.382} \\
\hline & 2.sinif & 64 & 104,33 & & & \\
\hline & 3.sinif & 54 & 121,00 & & & \\
\hline & 4.sinif & 57 & 121,14 & & & \\
\hline & Toplam & 226 & & & & \\
\hline \multirow{5}{*}{$\begin{array}{l}\text { Kendini } \\
\text { ödüllendirme }\end{array}$} & 1.Sinif & 51 & 108,04 & \multirow{5}{*}{3} & \multirow{5}{*}{4,365} & \multirow{5}{*}{.225} \\
\hline & 2.Sinif & 64 & 105,51 & & & \\
\hline & 3.Sinıf & 54 & 112,46 & & & \\
\hline & 4.Sinif & 57 & 128,34 & & & \\
\hline & Toplam & 226 & & & & \\
\hline \multirow{5}{*}{$\begin{array}{l}\text { Kendi kendine } \\
\text { konuşma }\end{array}$} & 1.Sinif & 51 & 107,89 & \multirow{5}{*}{3} & \multirow{5}{*}{1,643} & \multirow{5}{*}{.650} \\
\hline & 2.Sinif & 64 & 121,48 & & & \\
\hline & 3.Sinif & 54 & 108,77 & & & \\
\hline & 4.Sinif & 57 & 114,04 & & & \\
\hline & Toplam & 226 & & & & \\
\hline \multirow{5}{*}{$\begin{array}{l}\text { Düşünceleri } \\
\text { değerlendirme }\end{array}$} & 1.Sinif & 51 & 104,21 & \multirow{5}{*}{3} & \multirow{5}{*}{3,154} & \multirow{5}{*}{.368} \\
\hline & 2.Sinif & 64 & 109,30 & & & \\
\hline & 3.Sinif & 54 & 125,29 & & & \\
\hline & 4.Sinif & 57 & 115,36 & & & \\
\hline & Toplam & 226 & & & & \\
\hline \multirow{5}{*}{$\begin{array}{l}\text { Kendini } \\
\text { gözlemleme }\end{array}$} & 1.sinif & 51 & 125,37 & \multirow{5}{*}{3} & \multirow{5}{*}{,349 } & \multirow{5}{*}{.951} \\
\hline & 2.sinif & 64 & 101,62 & & & \\
\hline & 3.sinif & 54 & 119,79 & & & \\
\hline & 4.sinif & 57 & 110,26 & & & \\
\hline & Toplam & 226 & & & & \\
\hline \multirow{5}{*}{$\begin{array}{l}\text { Kendini } \\
\text { cezalandırma }\end{array}$} & 1.sinif & 51 & 116,31 & \multirow{5}{*}{3} & \multirow{5}{*}{4,626} & \\
\hline & 2.sinif & 64 & 113,38 & & & \\
\hline & 3.sinif & 54 & 115,21 & & & .201 \\
\hline & 4.sinif & 57 & 109,49 & & & \\
\hline & Toplam & 226 & & & & \\
\hline & 1.sinif & 51 & 118,29 & & & \\
\hline Hatırlatıcılar & 2.sinif & 64 & 112,71 & 3 & 385 & 943 \\
\hline belirleme & 3.sinif & 54 & 112,44 & 3 & (385, & .943 \\
\hline & 4.sinif & 57 & 111,10 & & & \\
\hline & Toplam & 226 & & & & \\
\hline & 1.sinif & 51 & 109,49 & & & \\
\hline $\begin{array}{l}\text { Dogal oduller } \\
\text { jizerinde }\end{array}$ & 2.sinif & 64 & 111,53 & & & \\
\hline üzerinde & 3.sinıf & 54 & 108,65 & 3 & 2,095 & .553 \\
\hline duşunceye & 4.sinif & 57 & 123,89 & & & \\
\hline & Toplam & 226 & & & & \\
\hline & 1.sinif & 51 & 108,21 & & & \\
\hline & 2.sinif & 64 & 109,08 & & & \\
\hline Toplam & 3.sinıf & 54 & 118,43 & 3 & 1,273 & .736 \\
\hline & 4.sinif & 57 & 110,92 & & & \\
\hline & Toplam & 226 & & & & \\
\hline
\end{tabular}


Tablo 5 incelendiğinde; okul öncesi eğitimi öğretmen adaylarının öz liderlik düzeylerinin sınıf düzeyine göre değişmediği görülmektedir ( $\left.\chi_{(3)}^{2}=1,123 ; \mathrm{p}>.05\right)$. Bu sonuç; üniversite eğitimleri boyunca okul öncesi eğitimi öğretmen adaylarının aldıkları eğitimlerin öz liderlik düzeylerine etki etmediği şeklinde açıklanabilir.

Tablo 6. Okul öncesi öğretmenliği öğretmen adaylarının akademik içsel motivasyonları ile öz liderlik düzeyleri arasındaki ilişki

\begin{tabular}{lccccc}
\hline & $\begin{array}{c}\text { Başarı } \\
\text { Gereksinimi }\end{array}$ & $\begin{array}{c}\text { Sosyal } \\
\text { Kabul }\end{array}$ & $\begin{array}{c}\text { Başarısızlık } \\
\text { Korkusu }\end{array}$ & Uzmanlık & $\begin{array}{c}\text { Motivasyon } \\
\text { Toplam }\end{array}$ \\
\hline Başarılı performans & $.261^{* *}$ & $.180^{*}$ & -.011 & $.254^{* *}$ & $.277^{* *}$ \\
Kendini ödüllendirme & .055 & $.186^{*}$ & -.030 & $.172^{*}$ & $.170^{*}$ \\
Kendi kendine konuşma & .121 & $223^{* *}$ & .070 & $.142^{*}$ & $.245^{* *}$ \\
Düşünceleri değerlendirme & $.212^{* *}$ & .043 & -.071 & $.258^{* *}$ & $.155^{*}$ \\
Kendini cezalandırma & -.078 & $-.273^{* *}$ & $-.307^{* *}$ & -.046 & $-.316^{* *}$ \\
Kendini gözlemleme & $.152^{*}$ & .038 & $-.192^{*}$ & $.180^{*}$ & .064 \\
Hatırlatıcıları belirleme & .097 & $.141^{*}$ & $-.137^{*}$ & $.270^{* *}$ & $.186^{*}$ \\
Doğal ödül & .120 & .114 & $-.158^{*}$ & $.178^{* *}$ & .108 \\
Öz liderlik Toplam & $.202^{* *}$ & $.135^{*}$ & -.137 & $.270^{* *}$ & $.186^{*}$ \\
\hline
\end{tabular}

${ }^{* *} \mathrm{p}<.001 ;{ }^{*} \mathrm{p}<.05$

Araştırmaya katılan okul öncesi öğretmen adaylarının öz liderlik toplam puanları ile akademik içsel motivasyon toplam puanları arasında pozitif yönde anlamlı bir ilişki olduğu saptanmıştır $(\mathrm{r}=.186 ; \mathrm{p}<.05)$. Okul öncesi eğitimi öğretmen adaylarının ölçeklerden aldıkları toplam puanların ortalamaları arasında pozitif yönde bir ilişki olması, öğretmen adaylarının akademik içsel motivasyonları arttıkça öz liderlik düzeylerinin de arttığını göstermektedir. Ancak öz liderlik alt boyutlarından kendini gözlemleme ( $\mathrm{r}=$ 064; $\mathrm{p}>.05)$ ve doğal ödülün $(\mathrm{r}=.108 ; \mathrm{p}>.05)$ öğretmen adaylarının motivasyonları arasında ve motivasyon alt boyutlarından başarısızlık korkusu ile öz liderlik ( $\mathrm{r}=-.011 ; \mathrm{p}>.05)$ arasında ilişkisi olmadığı da araştırma sonucunda belirlenmiştir.

\section{TARTIŞMA, SONUÇ VE ÖNERİLER}

$\mathrm{Bu}$ araştırma, okul öncesi eğitimi öğretmen adaylarının içsel motivasyonları ile öz liderlik algı düzeyleri arasındaki ilişkinin birtakım değişkenlere göre incelenmesi amacıyla yapılmıştır. Yapılan bu araştırma 
sonucunda okul öncesi eğitimi öğretmen adaylarının akademik içsel motivasyonlarının ve öz liderlik düzeylerinin ortalamanın üzerinde olduğu belirlenmiştir.

Okul öncesi eğitimi öğretmen adaylarının akademik içsel motivasyonlarının sınıf düzeyine göre değişmediği; sosyal kabul düzeylerinin ise sınıf düzeyine göre farklılaştığı ve birinci sınıf öğretmen adayları ile ikinci ve üçüncü sınıf öğretmen adayları arasında birinci sınıf öğretmen adayları lehine anlamlı farklılık olduğu belirlenmiştir. Şeker (2017) de müzik öğretmen adaylarının akademik motivasyonlarının orta düzeyde olduğunu ve akademik motivasyonun sınıf düzeyine göre değişmediğini belirlemiş̧tir. Ancak yapılan bazı araştırmalarda, öğretmen adaylarının akademik motivasyon düzeylerinin sınıf düzeyine göre farklılaştığını ve birinci sınıf öğretmen adaylarının akademik motivasyonlarının daha yüksek olduğu sonucuna ulaşılmıştır (Eymur ve Geban, 2011; Gömleksiz ve Serhatlığlu, 2013; Terzi ve Uyangör, 2017). Yine Uyulgan ve Akkuzu (2014) öğretmen adaylarının akademik içsel motivasyonlarının sınıf düzeyine göre farklılaştığını ve sınıf düzeyi yükseldikçe akademik içsel motivasyonun azaldığını belirlemişlerdir. $\mathrm{Bu}$ durumun yaşla bağlantılı olduğu ve yaş arttıç̧a akademik içsel motivasyonun düştüğü bazı araştırmalarda ifade edilmektedir (Hegarty, 2010; Uyulgan ve Akkuzu, 2014). Başaran ve Orhun (2013) öğretmen adaylarının motivasyonlarını en fazla Kamu Personeli Seçme Sınavı'nın içeriğinin ve uygulanış biçiminin düşürdügünü ifade etmektedir. $\mathrm{Bu}$ durumda öğretmen adaylarının dördüncü sınıfta hayatlarını belirleyecek olan sınava girmelerinin, akademik içsel motivasyonlarını olumsuz etkilediği söylenebilir. $\mathrm{Bu}$ araştırma sonucunda akademik içsel motivasyonun alt boyutlardan biri olan sosyal kabul düzeyinin sınıf düzeyine göre farklılaştığı ve sınıf düzeyi yükseldikçe öğretmen adaylarının sosyal kabul düzeylerinin düştügü belirlenmiştir. $\mathrm{Bu}$ durumda çok yakın bir zaman diliminde ögretmen olarak göreve başlayacak olan öğretmen adaylarının lisans eğitimi süresince akademik içsel motivasyonlarını destekleyici çalışmalara yeterince yer verilmediği, not kaygısının ve atanma kaygısının çalışmalarına olumsuz yansıdığı söylenebilir. Öğretmen adaylarının akademik içsel motivasyonlarını destekleyecek çalışmaların yapılmasının ve uygulama odaklı olarak yapılacak çalışmaların öğretmen olma isteğini daha fazla arttıracağ1 ve sosyal kabul düzeyleri ile beraber akademik içsel motivasyonlarını da olumlu yönde etkileyeceği düşünülmektedir.

Yapılan bu araştırmanın bulgularına bakılarak okul öncesi eğitimi ögretmen adaylarının öz liderlik düzeylerinin de sınıf düzeyine göre değişmediği belirlenmiştir. Ancak Göksoy, Emen ve Yenipınar (2014), 
öğretmenlerle yaptıkları çalışmada öğretmenlerin öz liderlik düzeylerinin yüksek olduğu sonucuna ulaşmıştır. Bu durum da öğretmenlerin sınıf yönetmeye başladıklarında kendilerini daha yetkin hissettikleri şeklinde yorumlanabilir. Bu nedenle öğretmen yetiştirme programlarında amaç sadece öğretmen çıktısı almak değil, öğretmen deneyimlerinin adaylara aktarılarak bütüncül bir şekilde mesleki bilinçlenmenin gerçekleşmesini sağlamaktır. Öğretmen adaylarının sadece öğretmenliğe başladıklarında değil eğitim süreçleri sırasında da kendilerini birer öğretmen olarak görmeleri uzun vadede daha olumlu mesleki deneyimler doğuracaktır.

Araştırmaya katılan okul öncesi öğretmen adaylarının öz liderlik toplam puan ortalamaları ile akademik içsel motivasyon toplam puan ortalamalarına bakıldığında iki değişken arasında pozitif yönlü anlamlı bir ilişki olduğu belirlenmiştir. Dolayısıyla öz liderlik arttıkça, akademik içsel motivasyonun arttı̆̆ söylenebilir. Ancak öz liderlik alt boyutlarından kendini gözlemleme ve doğal ödül ile öğretmen adaylarının motivasyonları arasında ve motivasyon alt boyutlarından başarısızlık korkusu ile öz liderlik arasında ilişki olmadığı da araştırma sonucunda belirlenmiştir. Bu durumda başarılı olmak ve başarmaya odaklanmak, öğretmen adaylarının akademik içsel motivasyonlarını arttırmakta ve öğretmen olmanın gereklerini yerine getirmeye daha istekli olduklarını göstermektedir. Nitekim Robert ve Foti (1998), öz liderlik düzeyleri yüksek olan bireylerin, yaptıkları işten tatmin olduklarını belirlemişlerdir. Dolayısıyla değişen dünyaya ayak uydurabilmek için öz liderlik düzeyi yüksek ve işini severek yapan bireylerin yetiştirilmesi gerekmektedir. $\mathrm{Bu}$ durum da öncelikle öğretmenlerin bu becerilerle donanmış olmasından geçmektedir.

Dolayısıyla lisans programlarında bölümlere göre hazırlanan ders içeriklerinde motivasyonu etkileyecek, başarı gereksinimini arttırmaya yönelik uygulamalı çalışmaların yapılması gerektiği düşünülmektedir. Ayrıca bu çalışmada kullanılan nicel araştırma yöntemi ile beraber nitel araştırmalarla da daha derinlemesine incelemeler yapılabileceği düşünülmektedir. Nitel araştırmalarla daha öznel ve ayrıntılı bir biçimde ögretmen motivasyonları ve liderlik düzeyleri incelendiğinde problemlerin kaynakları, sebepleri ve sonuçları daha net bir şekilde ortaya çıkabilir ve böylelikle bu sorunlar üzerinde yapılacak olan iyileştirme çalışmaları yoğunlaştırılabilir. 


\section{KAYNAKÇA}

Akar, H. ve Aydın, S. (2016). Öğretim elemanlarının mesleki yeterliklerini gerçekleştirme düzeyleri ile öğrencilerin akademik motivasyonu arasındaki ilişki. Journal of International Social Research, 9(43), 1344-1352.

Başaran, M. ve Dedeoğlu Orhun, B. (2013). Öğretmen adaylarının mesleğe ilişkin motivasyonlarını etkileyen faktörler. İnönü Üniversitesi Ĕgitim Fakültesi Dergisi 14, (3), 129-151.

Beycioglu, K. ve Aslan, B. (2010). Teacher leadership scale: A validity and reliability study. Elementary Education Online, 9(2), 764-775.

Büyüköztürk, S., Kılı̧̧ Çakmak, E., Akgün, Ö. E., Karadeniz, S. ve Demirel, F. (2012). Bilimsel araştırma yöntemleri (18. Baskı). Ankara: Pegem Akademi Yayıncılık.

Elloy, D. F. (2008). The relationship between self-leadership behaviors and organization variables in a selfmanaged work team environment. Management Research News, 31(11).

Eymur, G. and Geban, Ö. (2011). An investigation of the relationship between motivation and academic achievement of pre-service chemistry teachers. Education and Science, 36(161), 246-255.

Göksoy, S., Engin, E. M. E. N. ve Yenipınar, Ş. (2014). Öğretmenlerin öz liderlik rolleri ile örgütsel vatandaşlık davranışları arasındaki ilişkinin incelenmesi. Kahramanmaraş Sütçü İmam Üniversitesi Sosyal Bilimler Dergisi, 11(1), 103-116.

Gömleksiz, M. N. ve Serhatlığlu, B. (2013). Okul öncesi öğretmenlerinin öz-yeterlik inançlarına ilişkin görüşleri. Electronic Turkish Studies, 8(7), 201-211.

Hegarty, N. (2010). Application of the academic motivation scale to graduate school students. The Journal of Human Resource and Adult Learning, 6(2), 48-55.

Jacobsen, D. A., Eggen, P. and Kauchak, D. (2002). Methods for teaching, promoting student learning (6th Ed.). New Jersey: Meririll Prentice Hall.

Karasar, N. (2009). Bilimsel araştırma yöntemleri. Ankara: Nobel Yayınları

Kocabaş, İ. ve Karaköse, T. (2005). Okul müdürlerinin tutum ve davranışlarının öğretmenlerin motivasyonuna etkisi (özel ve devlet okulu örneği). Türk Eğitim Bilimleri Dergisi, 3(1), 79-93.

Koyuncu, K. (2016) Okul öncesi eğitimi öğretmen adaylarının akademik içsel motivasyonlarının çeşitli değişkenler açısından incelenmesi. Yüksek Lisans Tezi. Çanakkale Üniversitesi Eğitim Bilimleri Enstitüsü.

Manz, C. C. (1986). Self-leadership: toward an expanded theory of self- influence processes in organizations. Academy of Management Review, 11(3), 585- 600.

Manz, C. C. (1992). Self-leadership the heart of empowerment. The Journal for Quality and Participation, 15(4), 80.

Öztürk, T. (2006). Illköğretim ögretmenlerinin motivasyonunu artıran ve idame ettiren faktörler. Yayımlanmamış Yüksek lisans tezi, Beykent Üniversitesi, İstanbul.

Prussia, G. E., Anderson, J. S. and Manz, C. C. (1998). Self-leadership and performance outcomes: The mediating influence of self-efficacy. Journal of Organizational Behavior, 523-538. 
Robert, H.E. and Foti, R.J. (1998). Evaluating the interaction between self- leadership and work structure in predicting job satisfaction. Journal of Business and Psychology, 12(3), 257-267.

Ryan, R. M., and Deci, E. L. (2000). Intrinsic and extrinsic motivations: Classic definitions and new directions. Contemporary Educational Psychology, 25(1), 54-67.

Stewart, G. L., Courtright, S. H., and Manz, C. C. (2011). Self-leadership: A multilevel review. Journal of Management, 37(1), 185-222.

Şeker, S. S. (2017). Müzik eğitimi bölümü öğretmen adaylarının akademik güdülenme ve akademik öz-yeterlik düzeylerinin incelenmesi. Abant İzzet Baysal Üniversitesi Ĕ̌itim Fakültesi Dergisi, 17(3), 1465-1484.

Tabak, A., Sı ğrı, Ü. ve Türköz, T. (2013). Öz liderlik ölçeğinin türkçeye uyarlanma çalışması. Bilig, 67, 213-246.

Terzi,A.R. ve Uyangör, N. (2017). Eğitim fakültesi öğretmen adaylarının akademik motivasyonları ve algıladıkları okul iklimi ilişkisi. Journal of Current Researches on Social Sciences, 7(4), 13-24.

Uyulgan, M. A. and Akkuzu, N. (2014). An overview of student teachers' academic intrinsic motivation. Educational Sciences: Theory and Practice, 14(1), 24-32.

Wilkesmann, U., Fischer, H. and Virgillito, A. (2012). Academic motivation of students-the German case. Dortmund: Zentrum für Weiterbildung.

Yazıcı, H. (2009). Öğretmenlik mesleği, motivasyon kaynakları ve temel tutumlar: kuramsal bir bakış. Kastamonu Ĕgitim Dergisi, 17(1), 33-46.

Zapalska, A. M., Kelley, T. and Zieser, N. (2015). Strategies for self-leadership development: an example of the us coast guard academy. International Journal of Business \& Public Administration, 12(2), 66-75.

\section{EXTENDED ABSTRACT}

As a result of the technologic and scientific changes exist in the present day; teachers that make the students active, motivate them and cooperate with other students, teachers and administrators are needed. Accordingly learning environments must change, changing needs of the students must be met and the teachers must resilience to these changes. Meeting these needs the teachers, who have high internal motivation, knows their power well and use it correctly are needed. Beginning from preschool period rearing individuals, who have high academic internal motivation and self-leadership levels the existence of the teachers, who have high motivation and self-leadership, is very important. Regarding this situation, these features of teacher candidates must be developed and supported before they start their job. The purpose of this research is to reveal the relation between academic internal motivation and self-leadership levels of preschool teacher candidates. In this direction class grade, age, the reason for choosing the department and their selfleadership and academic internal motivation will be examined according to their state of wanting to practise their profession or not. Within this research, which was carried out to determine the academic internal motivation and the self-leadership of the preschool teacher candidates, relational screening model was used. The 
relational screening model is used for determining the relation between the variables. The study group of the research consists of totally 226 teacher candidates $51(22,6 \%)$ first grade, $64(28,3 \%)$ second grade, 54 (23,9\%) third grade and 57 $(25,2 \%)$ fourth grade who attend Uludağ University Faculty of Education Preschool Education Department. 90.7\% ( $\mathrm{f}=205)$ of the teacher candidates are female and $9.3 \%(f=21)$ of them is male. $88.1 \%(f=199)$ of the teacher candidates chose to be a teacher at their own request and $92 \%(\mathrm{f}=208)$ of them want to be a teacher. Within the research "Self-leadership Scale" which was developed by Anderson and Prussia (1997) and adapted into Turkish by Tabak, Sığrı and Türköz (2013) and also 'Academic Internal Motivation Scale' and 'Personal Information From' which were adapted into Turkish by Uyulgan and Akkuzu (2014) were used. Academic internal motivation scale consists of 23 items and it is 7 likert type scale. It consists of 4 subdimensions, which are the necessity of success, social acknowledgement, the fear of failure and proficiency. On the other hand self-leadership scale consists of 29 items and it is 5 likert type scale. The self-leadership scale consists of 8 sub-dimensions self-rewarding, soliloquizing, imagining successful performance determining a goal, determining reminders, self punishing, self observe, evaluating ideas/thoughts and focusing the thinking on natural rewards. The cronbach alpha reliability coefficient of the academic internal motivation scale was .77 and reliability coefficient of the self-leadership scale was found .89. Considering both scales it can be said that they are reliable. The datum of the research was evaluated after being analysed in the SPSS (Statistical Package for Social Sciences) package program. The analysis of the datum was carried out in two stages. In the first stage it was evaluated in terms of normality and in the second stage sub-problems were solved. As a result of the Kolmogorov-Smirnov normality test it was determined that the distribution was not normal. According to the data obtained from the research whether the academic internal motivation and the self-leadership of the preschool teacher candidates change according to their class grade or not was determined with Kruskall Wallis- $\mathrm{H}$ $(\mathrm{KWH})$ test. As a result of the Kruskall Wallis-H test when a significant difference was found Mann Whitney $U$ test was performed on binary combinations of the groups. In addition the relation between the academic internal motivations and selfleadership levels of the teacher candidates was analyzed with Pearson Correlation Coefficient method. Also the self-leadership levels of the preschool teacher candidates, was examined with multi regression together with determining reminders, successful performance, self rewarding, soliloquizing, evaluation ideas, self- punishing and self observation sub-dimensions and the predictive power of academic internal motivation. As a result of the research it was determined that academic internal motivation of the preschool teacher candidates do not change according to class grade; their social acknowledgement levels differ according to class grade and there was a significant difference between first grade teacher candidates and second and third grade teacher candidates on behalf of the first grade teacher candidates. It was inferred that the average point that the preschool teacher candidates scored from Academic Internal Motivation Scale was 102.23. Considering the fact that the highest point that can be scored from the scale was 161 it can be said that the academic internal motivation of the teacher candidates is 
above the average. Considering the points that the preschool teacher candidates scored from the Self-leadership Scale it is seen that the average is 111,05. Again considering the fact that the highest point that can be scored from the scale is 145 it can be said that the self-leadership of the teacher candidates is also above the average. Within this research, in which the relation between academic internal motivation and the self-leadership levels of the preschool teacher candidates is examined, it was determined that there is a positively significant relation between self-leadership total attitude scores and academic internal motivation total scores of the preschool teacher candidates. Accordingly it can be said that as long as selfleadership increases academic internal motivation increases as well. However as a result of the research it was determined that there was not a relation between teacher candidates' motivations and self-observation and natural reward; which were among self-leadership sub-dimensions; and fear of failure and self-leadership; which were among motivation sub-dimensions. In this case being successful and focusing on success increase the internal motivation of teacher candidates and indicates that they are more voluntary for doing the requirements of being a teacher. In order to keep up with the changing world it is necessary to rear teachers who have high level of selfleadership and like doing their job. In the circumstances first of all the teacher must be equipped with these skills. Accordingly it will be useful to perform applied studies in the lesson contents prepared according to the departments' undergraduate programs regarding increasing the success requirements and that will affect motivation. 
